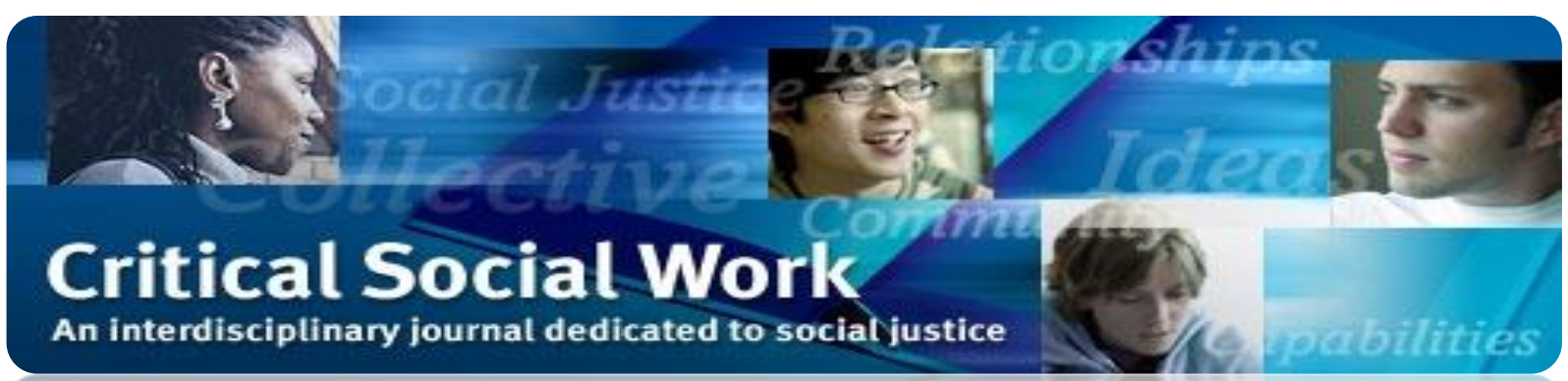

\title{
Critical Social Work
}

School of Social Work

University of Windsor

167 Ferry Street

Windsor, Ontario N9A 0C5

Email: cswedit@uwindsor.ca

Publication details, including instructions for authors and subscription information can be found at: http://uwindsor.ca/criticalsocialwork

Critical Social Work, 2018 Vol. 19, No. 2 
Forrest

\title{
A Life Lesson
}

\section{Critical Social Work 19(2)}

\author{
Brandi Forrest
}

Something rather significant happened to me and I want to tell you about it....

A man I had the privilege and honour of caring for passed away. To look at him no one could say he was handsome, but I don't think I have ever met a more beautiful person. He had a profound effect on me and I don't think I will ever look at life the same.

He was abandoned as a youngster by his family and grew up in a Goffmanesque total institution. I don't dare think of the horrors and abuse he was subjected to there. He was afflicted with large external tumors on his head that would grow until they burst. He lived for years with large open wounds because of this. With such a past I don't think anyone could be unaffected, but you wouldn't have ever guessed he suffered any tragedy in his life. He was always happy. This man loved people and he made you feel like you were worth more than the world, until someone else walked into the room. His laugh was screechy and high pitched like a prehistoric bird, but it made you smile no matter what. The most he would ever want from you was a smile and to hold your hand or to get a hug. He was very clever at getting all three things from you whenever he wanted.

He did give the best hugs.

There are too many people I know that hold on to such negative feelings and emotions. It makes them into an unpleasant person to be around. The very air about them is changed and uncomfortable. This man was the complete opposite. Nothing ever left him sad or angry for long. His perspective was so innocent and positive that I can't help but want to emulate that in my life. The things he loved always seemed to fascinate him; as if the magic or wonder of it was always there and never faded.

His greatest pleasure was having someone's attention or simply holding a balloon in his hand. He didn't need extravagant things or events to be happy. He took every day for what it was and made it the best he could.

He was selfless beyond reason. He could be suffering from a near catastrophic injury resulting from his condition and be more concerned about me than him. I'll never forget him rubbing my back and cooing at me while I thought he was going to die in my arms. I could only thank him in the end. He showed me that nothing is set unless I set it. Happiness doesn't just happen, you let it or make it happen and holding onto negativity doesn't do a damn thing. I understand the phrase "live in the moment" much better now or at least in a much different way.

I wish you could have met him, but I think you already understand the lesson he taught me. I will miss him but won't mourn him. He wouldn't even see the point in sorrow. At least that's what I believe. 